\title{
RELATOS E EXPERIÊNCIAS SOBRE NÓS, OS DE ARUANDA!
}

\author{
Arthur Leandro/ Tata Kinamboji ${ }^{1}$
}

Resumo: Nós de Aruanda: Artistas de Terreiro é um Projeto de exposição coletiva com protagonismo de artistas de terreiros e curadoria coletiva, que acontece em Belém do Pará desde 2013 com o objetivo de reunir artistas de comunidades dos povos tradicionais de matriz africana (terreiros) em uma exposição com obras oriundas do cotidiano dessas comunidades e que revelam a produção poética dos artistas visuais de terreiros, fazer circular informações sobre a produção artística com o protagonismo desses povos, contribuir com a implantação da Lei $10.639 / 03$, e incentivar a ocupação de espaços dos equipamentos culturais pelo povo negro. A necessidade de inserção dos artistas de terreiros no circuito de artes visuais surgiu no final de 2011 como um 'insight' durante as aulas da disciplina "Poéticas Afro-amazônicas" para o curso de especialização em 'Educação para as relações etnico-raciais' ofertado pelo Grupo de Estudos Afro-Amazônicos - GEAAM/ UFPA. Foi nessas aulas, em que tínhamos o objetivo de subsidiar o ensino de arte e cultura afro-brasileiras e contribuir com a implantação da Lei 10.639/2003, que percebemos que a maioria das obras que a história da arte registra como "arte afro-brasileira" são de artistas euro-descendentes que não fazem parte de comunidades tradicionais de matrizes africanas, e, ao fim, o que percebemos é um olhar preconceituoso sobre as práticas tradicionais afro-brasileiras, produzido por artistas que apenas se valem da temática étnico-racial para usá-las em trabalhos sem nenhum envolvimento ou aprofundamento sobre as relações étnico-raciais na diáspora brasileira. O que apresentamos aqui é um recorte, uma colcha costurada com diversos retalhos de relatos de experiências, no plural, de entrevistas de artistas e outras tramas que recompõem a memória de cinco séculos de presença negra na Amazônia, e cinco anos de um projeto que visa renegrir as artes visuais no Estado do Pará.

Palavras-chave: Nós de Aruanda, artistas de terreiro; poéticas de resistência negra; culturas tradicionais de matriz africana; arte afro-brasileira; Artes Visuais; ensino de Artes Visuais; Lei $10.639 / 03$.

\section{STORIES AND EXPERIENCES ABOUT NÓS DE ARUANDA: ARTISTAS DE TERREIRO}

\begin{abstract}
Nós de Aruanda: Artistas de Terreiro is a project of collective exhibition with protagonism of artists from terreiros and collective curatorship, which happens in Belém do Pará since 2013, made with the objective of bringing together artists from communities of the traditional African peoples (terreiros de candomblé) in an exhibition with works originating from the daily life of these communities and that reveal the poetic production of the black visual artists of terreiros, to circulate information about artistic production with the protagonism of these peoples, to contribute to the implementation of Law 10.639 / 03, and to encourage the occupation of spaces of cultural equipment by the black people. The need to insert artists from terreiros into the circuit of visual arts appeared at the end of 2011 as an 'insigth' during the classes of the discipline "Poetic Afro-Amazonian" for the specialization course in 'Education for ethnic-racial relations' offered by the Afro-Amazonian Studies Group - GEAAM / UFPA. It was in these classes that we aimed to subsidize the teaching of Afro-Brazilian art and culture and contribute to the implementation of Law 10.639 / 2003, that we perceive that most of the works

\footnotetext{
${ }^{1}$ In Memorian. Professor da Faculdade de Artes Visuais da Universidade Federal do Pará (FAV/UFPA), membro do Grupo de Estudos Afro-Amazônico (NEAB) da UFPA, Mestre em História da Arte pela Escola de Belas Artes da Universidade Federal do Rio de Janeiro (EBA/UFRJ), Tata Kisikar'Ngomba ria Nzumbarandá, povo bantu. Esse artigo foi um de seus últimos trabalhos.
} 
that the history of art registers as "Afro-Brazilian art" are of Euro-descendent artists who are not part of traditional communities of African matrices. So what we perceive is a biased view of Afro-Brazilian traditional practices. produced by artists who only use the ethnic-racial theme to use them in works without any involvement or deepening on ethnic-racial relations in the Brazilian diaspora. It is a cut, a quilt stitched together with several pieces of reports of experiences in the plural of artist interviews and other plots that recompose the memory of five centuries of black presence in the Amazon, and five years of a project aimed at re-being black in the visual arts in the State of Pará.

Key-words: Nós de Aruanda; artistas de terreiro; poetics of black resistance; african matrix conversations; afro-brazilian Art; Visual arts; teaching Visual Arts; Law 10.639 / 03.

\section{RÉCITS ET EXPÉRIENCES SUR NÓS DE ARUANDA: ARTISTAS DE TERREIRO}

Résumé: Nós de Aruanda: Artistas de Terreiro est un projet d'exposition collective d'artistes et de commissaires d'exposition qui se déroule à Belém do Pará depuis 2013 dans le but de rassembler des artistes issus des communautés de peuples africains traditionnels (terreiros de candomblé) au sein d'une exposition présentant des œuvres de la vie quotidienne de ces derniers - Ce projet révèlent la production poétique d'artistes visuels de terreiros, diffusent des informations sur la production artistique avec le protagonisme de ces peuples, contribuent à la mise en œuvre de la loi 10.639 / 03 et encouragent l'occupation des espaces par des Noirs. La nécessité d'insérer des artistes de terreiro dans le circuit des arts visuels est apparue à la fin de 2011 comme une "insight" lors des cours de la discipline "Poétique afro-amazonienne" du cours de spécialisation "Éducation aux relations entre ethnies et races", par le Groupe d'Études Afroamazoniennes - GEAAM / UFPA. C'est dans ces cours que nous avons eu pour objectif de subventionner l'enseignement de l'art et de la culture afro-brésiliens et de contribuer à l'application de la loi 10.639 / 2003, selon laquelle la plupart des œuvres que l'histoire de l'art a répertoriées comme "art afro-brésilien "appartiennent à des artistes d'origine européenne qui ne font pas partie des communautés matricielles africaines traditionnelles et, en fin de compte, nous percevons un regard biaisé sur les pratiques afro-brésiliennes traditionnelles. produites par des artistes qui utilisent uniquement le thème ethno-racial pour les utiliser dans des œuvres sans aucune implication ou approfondissement des relations entre ethnies et races dans la diaspora brésilienne. Nous présentons ici une coupe, ou plusieurs reportages sur des expériences plurielles d'interviews d'artistes qui recomposent le souvenir de cinq siècles de présence noire en Amazonie et de cinq ans d'un projet vise à rendre noir les arts visuels dans l'État de Pará, au Brésil.

Mots-clés: Nós de Aruanda: artistas de terreiro; poétique de la résistance noire; cultures africaines traditionnelles; art afro-brésilien; Arts visuels; enseignement des arts visuels; Loi $10.639 / 03$.

\section{¡ INFORMES Y EXPERIENCIAS SOBRE NÓS, OS DE ARUANDA!}

Resumen: Nós, os de Aruanda: artistas de Terreiro es un proyecto de exposición colectiva con protagonismo de artistas de terreiros de candomblé y comisariado colectivo, que tiene lugar en Belém do Pará desde 2013 con el objetivo de reunir artistas de comunidades de pueblos tradicionales de matriz Africano (terreiros) en una exposición con obras de la vida cotidiana de estas comunidades y que revelan la producción poética de los artistas visuales de terreiros, circulan información sobre la producción artística con el protagonismo de estos pueblos, contribuyen a la aplicación de la Ley 10.639/03, y fomentar la ocupación de espacios de equipamientos culturales por el pueblo negro. La necesidad de insertar a los artistas de terreiros en el circuito de artes visuales surgió al final de 2011 como un "insigth" durante las clases de la disciplina "Poética afro-amazónicos " para el curso de especialización en ' Educación para las 
relaciones étnico-raciales ' ofrecido por el grupo de estudio afro-amazónico - GEAAM/UFPA. Fue en estas clases, en las que tuvimos el objetivo de subvencionar la enseñanza del arte y la cultura afro-brasileña y contribuir a la implementación de la Ley 10.639/2003, que nos dimos cuenta de que la mayoría de las obras que la historia del arte se registra como "arte afro " son de los artistas euro-descendientes que no son parte de las comunidades tradicionales de las matrices africanas, y al final, lo que percibimos es una mirada prejuiciosa a las prácticas afro tradicionales. Producido por artistas que sólo valen el tema étnico-racial para utilizarlos en obras sin ninguna implicación o profundización de las relaciones étnico-raciales en la diáspora brasileña. Lo que presentamos aquí, es un recorte, un edredón cosido con varios informes de experiencias, plural, entrevistas de artistas y otras parcelas que recomponemos la memoria de cinco siglos de presencia negra en el Amazonas, y cinco años de un proyecto que busca desobedescarse de las artes visuales en el estado de Pará.

Palabras clave: Nós, os de Aruanda, artistas de terreiro; poéticas de la resistencia negra; culturas tradicionales de la matriz africana; arte afro-brasileño; Artes Visuales; enseñanza de artes visuales; Ley 10.639/03.

O nosso atraso político, que tornou essa ditadura necessária, se explica perfeitamente pelo nosso sangue negro. Infelizmente. Por isso, estamos tentando expurgar esse sangue, construindo uma nação para todos, "embranquecendo" a raça brasileira. Osvaldo Aranha - Ministro das Relações Exteriores de Getúlio Vargas, para Ruth Landes (em 1937), ao saber do interesse da antropóloga norte-americana em estudar os negros da Bahia (Landes, 2002. p 41).

É bem verdade que o Brasil se construiu pela imagem europeia. Em Raízes do Brasil, Sérgio Buarque de Holanda (1995) coloca em debate o choque entre a tradição e modernidade na sociedade brasileira. Para ele,

Trazendo de países distantes nossas formas de convívio, nossas instituições e nossa visão do mundo, a formação do Brasil está atrelada ao legado político, institucional e cultural da colonização, um legado que tenta nos aproximar da Europa, mas por uma aproximação que se dá pela aparência e não pela essência (...) antes de perguntar até que ponto poderá alcançar bom êxito a tentativa, caberia averiguar até onde temos podido representar aquelas formas de convívio, instituições e ideias de que somos herdeiros. (Holanda, 1995, p. 31).

Para os colonizadores, os negros africanos que foram trazidos na condição de escravos eram mera mercadoria, e como mercadoria não possuíam humanidade, e sem humanidade não possuíam cultura, ou, quando reconheciam a cultura desses povos, elas eram menosprezadas. Montserrat e Guibernau (1997, p. 100-101) nos explicam que "os colonizadores achavam que os povos nativos deveriam ser gratos a eles", uma vez que, de certo modo, ser explorado era um privilégio: significava estar em contato com uma 
cultura inequivocamente "superior" e "nesses terrenos, procuram apoiar uma estrutura de classe que os beneficie".

Sendo o modelo europeu uma diretriz a ser alcançada pela colônia portuguesa e pelos governos brasileiros no Império e também na República, é fácil perceber que as culturas e as artes de origem africanas e indígenas foram ignoradas pelas políticas públicas na educação e na cultura, e massacradas em violenta repressão estatal. O que vivemos nos dias de hoje é resultado de mais de quinhentos anos de violência colonizadora a perseguir, proibir e desprezar as culturas afro-brasileiras e indígenas para impor a matriz europeia, internalizada como natural. Um processo calcado na ideologia racista do embranquecimento.

Kabengele Munanga (2003) afirma que o racismo é uma ideologia essencialista que postula a divisão da humanidade em grandes grupos chamados raças contrastadas que têm características físicas hereditárias comuns, sendo estas os últimos suportes das características psicológicas, morais, intelectuais e estéticas e se situam numa escala de valores desiguais. Visto deste ponto de vista, o racismo é uma crença na existência das raças naturalmente hierarquizadas pela relação intrínseca entre o físico e o moral, o físico e o intelecto, o físico e o cultural. O racista cria a raça no sentido sociológico, ou seja, a raça no imaginário do racista não é exclusivamente um grupo definido pelos traços físicos. A raça na cabeça dele é um grupo social com traços culturais, lingüísticos, religiosos, etc. que ele considera naturalmente inferiores ao grupo a qual ele pertence. De outro modo, o racismo é essa tendência que consiste em considerar que as características intelectuais e morais de um dado grupo, são conseqüências diretas de suas características físicas ou biológicas.

Andreas Hofbauer (1999) explica que o branqueamento é uma categoria analítica usada em vários sentidos, ora é usada para tratar da questão da internalização dos modelos culturais hegemônicos dos brancos pelo povo negro - o que resulta na perda do seu ethos de matriz africana e na tentativa de parecer branco pela negação de suas origens - ora é tratado como o processo biológico de "clareamento" da população brasileira através da análise dos investimento oficiais em imigração de população europeia, da valorização positiva da mestiçagem ou dos dados demográficos registrados nos censos oficiais e previsões estatísticas do final do século XIX e início do XX sobre a categoria analítica do branqueamento. 


\section{UM MUNDO EURO-NORMATIVO, A ESCOLA NACIONAL DE BELAS ARTES A DETERMINAR A BRANQUITUDE NA VISUALIDADE BRASILEIRA}

E de repente, a colônia americana tinha sido elevada à condição de capital do Império Ultramarino de Portugal. Com a chegada da Corte lusitana ao Rio de Janeiro, em 1808, a Colônia teve de se adaptar à nova condição de capital do reino, e para isso a monarquia portuguesa criou instituições com as quais pudesse governar as terras de seus domínios em quatro continentes. Esse foi o início da construção do aparato burocráticoestatal necessário para atender as novas exigências de sede do governo português. E assim nasceram as primeiras instituições públicas de arte e cultura no Rio de Janeiro.

O Brasil vivia um dos momentos mais importantes de sua história artística, o barroco mineiro, movimento cultural que nos dias de hoje chama a atenção de pesquisadores de todas as partes do mundo. Mas mesmo hoje, quando o barroco mineiro pode ser considerado um "orgulho nacional", as escolas de arte ainda omitem a negritude de Antônio Francisco Lisboa, e também omitem o fato de que a arte produzida em seu atelier/oficina também estava impregnada do simbolismo e das referências visuais da matriz africana que lhe habitava, e essa percepção da negritude na produção artística e na visualidade da nova capital do reino, também parece ter sido um problema para a corte portuguesa que se instalava no Rio de Janeiro.

Eram os negros os responsáveis por (quase) tudo o que se produzia no Brasil Colônia, do alimento à construção das casas e das igrejas, das panelas aos altares e às esculturas de santos católicos, e é lógico que em tudo o que era produzido havia as marcas da matriz cultural de seus produtores. D. João VI dá indícios de que a corte portuguesa estranhou as marcas africanas na visualidade do Brasil-Colônia quando decreta que:

o estudo das Bellas Artes com applicação e referencia aos officios mecanicos, cuja pratica, perfeição e utilidade depende dos conhecimentos theoricos daquellas artes e diffusivas luzes das sciencias naturaes, physicas e exactas e querendo para tão uteis fins aproveitar desde já a capacidade, habilidade e sciencia de alguns dos estrangeiros benemeritos, que tem buscado a minha real e graciosa protecção ${ }^{2}$ (Portugal; Brasil, 1816)

\footnotetext{
2 Decreto de 12 de Agosto de 1816 - "Concede pensões a diversos artistas que vieram estabelecer-se no paiz." Attendendo ao bem commum que provém aos meus fieis vassallos de se estabelecer na Brazil um
} 
Com esse decreto, ignora a existência de artistas locais, paga pensões a artistas estrangeiros, declara a dependência da produção de 'belas artes' aos conhecimentos das 'luzes' (do Iluminismo europeu), diretrizes que vão se reproduzir em toda a política oficial de ensino e fomento das artes visuais que persiste até os nossos dias. E esse indício reforça a hipótese da urgência na criação da Academia de Belas Artes como parte fundamental do processo de dominação pela hegemonia cultural europeia na produção da visualidade brasileira.

Mas não é somente na estética a intervenção que a Academia de Belas Artes exerce no Brasil, a missão francesa (e toda a política pública na cultura que se instala a partir de sua chegada) também vai gradativamente inserir a noção do artista como o 'gênio criador'.

Leandro e Lago (2015) enfatizam que, enquanto "o modelo europeu valoriza o gênio artístico, ou seja, a potência criativa do indivíduo, a matriz africana é essencialmente coletivizada em comunidades", e alertam que "a missão francesa trouxe consigo a lógica de produção capitalista individualizada", e que a matriz africana vai perdendo o espaço que tinha na produção artística.

Escola Real de Sciencias, Artes e Officios, em que se promova e diffunda a instrucção e conhecimentos indispensaveis aos homens destinados não só aos empregos publicos da administração do Estado, mas tambem ao progresso da agricultura, mineralogia, industria e commercio, de que resulta a subsistencia, commodidade e civilisação dos povos, maiormente neste Continente, cuja extensão, não tendo ainda o devido e correspondente numero de braço indispensaveis ao tamanho e aproveitamento do terreno, precisa dos grandes soccorros da estatistica, para aproveitar os productos, cujo valor e preciosidade podem vir a formar do Brazil o mais rico e opulento dos Reinos conhecidos; fazendo-se portanto necessario aos habitantes o estudo das Bellas Artes com applicação e referencia aos officios mecanicos, cuja pratica, perfeição e utilidade depende dos conhecimentos theoricos daquellas artes e diffusivas luzes das sciencias naturaes, physicas e exactas; e querendo para tão uteis fins aproveitar desde já a capacidade, habilidade e sciencia de alguns dos estrangeiros benemeritos, que tem buscado a minha real e graciosa proteç̧ão para serem empregados no ensino e instrucção publica daquellas artes: Hei por bem, e mesmo emquanto ás aulas daquelles conhecimentos, artes e officios não formam a parte integrante da dita Escola Real das Sciencias, Artes e Officios que eu houver de mandar estabelecer, se pague annualmente por quarteis a cada uma das pessoas declaradas na relação inserta neste meu real decreto, a assignada pelo meu Ministro e Secretario de Estado dos Negocios Estrangeiros e da Guerra, a somma de 8:032\$000 em que importam as pensões, de que por um effeito da minha real munificiencia e paternal zelo pelo bem publico deste Reino, lhes faço mercê para a sua subsistencia, pagas pela Real Erario, cumprindo desde logo cada um dos ditos pensionarios com as obrigações, encargos e estipulações que devem fazer a base do contracto, que ao menos pelo tempo de seis annos hão de assignar, obrigando-se a cumprir quanto fôr tendente ao fim da proposta instrucção nacional, das bellas artes, applicadas á industria, melhoramento e progresso das outras artes e officios mecanicos. O Marquez de Aguiar, do Conselho de Estado, Ministro Assistente ao Despacho, encarregado interinamente da Repartição dos Negocios Estrangeiros e da Guerra assim o tenha entendido, e faça executar com os depachos necessarios. Palacio do Rio de Janeiro 12 de Agosto de 1816. Com a rubrica de Sua Magestade. Publicação: Coleção de Leis do Império do Brasil 1816, Página 77 Vol. 1 ver em http://bd.camara.gov.br/bd/handle/bdcamara/18330 
O fato é que desde então a presença negra nas artes visuais brasileiras enfrenta o mais cruel apagamento, pois na mesma medida que é quase impossível falar de um único ritmo musical brasileiro que não tenha influência africana, é uma tarefa dificílima encontrar artistas negros e poéticas de matriz afro-brasileira nas artes visuais no modernismo e na produção contemporânea brasileira. (Leandro e Lago, 2015, p 12)

A sociedade africana tradicional [...] é por natureza coletivista; o socialismo é, portanto, já presente dentro da sociedade africana, onde o capitalismo é o elemento estranho trazido pela colonização ${ }^{3}$ (Benot, 1969 apud Lippold, 2014). A lógica do gênio criador na política pública para as artes visuais interfere nessa produção comunitária e provoca o desaparecimento dos ateliês e oficinas coletivas de produção de arte.

É possível que esteja nessa lógica a notória preferência da população negra para a música, a dança e os esportes, e que a preferência se justifique por se tratar de expressões culturais que envolvem grande participação comunitária, em contrapartida dessa percepção da individualidade imposta pela academia de Belas Artes para as artes visuais. E, ainda, como os negros foram relegados às camadas marginalizadas da sociedade e da economia brasileira, também estavam menos aparelhados para competirem com o artista branco em um sistema cuja formação individualista necessitava de grandes despesas. (Leandro e Lago, 2015, p 12)

E, ainda, na política pública para a Cultura luso-brasileira, esse mesmo estado que financiou a hegemonia da identidade europeia, reprimiu com violência as manifestações de cultura de identidades de matriz africana. Considerando a chegada da corte portuguesa como início da institucionalidade brasileira, já em 1814 o governo geral do Rio de Janeiro recomendava ao governador da Bahia:

Determina Sua Alteza Real que V. Exa. proíba absolutamente os ajuntamentos de Negros chamados vulgarmente batuques, não só de dia, mas muito particularmente de noite, pois ainda que se lhes permitisse isto para os fazer contentes não deve continuar esta espécie de divertimento, depois de terem abusado tanto dela. (Reis, 1995)

\footnotetext{
3 “"...]la société africaine traditionnelle [...] est par nature collectiviste; le socialisme est donc déjá présent dans la société africaine, où le capitalisme est l'élément étranger apporté par la colonisiation." (Benot, 1969 apud Lippold, 2014) [tradução nossa]

${ }^{4}$ Uma das formas de fazer com que os africanos não esquecessem suas divisões de origem era, pensava o conde dos Arcos, permitir que eles praticassem seus batuques livremente. Nestes, que o inteligente conde percebera serem rituais étnicos, cada grupo africano tentava manter sua integridade cultural, dificultando a formação de uma frente pan-africana contra os brancos. Os senhores não entendiam assim, no que foram apoiados pela Corte. Em carta para Arcos, o marquês de Aguiar ordenava a proibição dos batuques africanos na Bahia (Reis, 1995).
} 
Essa determinação se espalhou em todo o território nacional durante o Brasil Colonial e o Brasil Império. Foi reproduzida nos códigos de posturas municipais, como por exemplo: no Pará a repressão às culturas negras eram legalmente justificadas pelo artigo 107 do código de posturas municipais de Belém, que proibia, entre outras coisas, “- $\S 2^{\circ}$. Fazer batuques ou sambas; $\S 3^{\circ}$. Tocar tambor, carimbó ou qualquer instrumento, que perturbe o sossego durante a noite, etc" (Belém/PA, 1880).

Mesmo no Brasil República do século XX, ainda temos o estado a reprimir as culturas afro-brasileiras. Leal (2011) diz que as culturas de matriz africana preservadas em comunidades tradicionais de terreiro, principalmente em seus aspectos religiosos, foram tratadas sob um rigor repressivo não fundamentado diretamente na legislação criminal brasileira, salvo em alguns casos por ser associada à prática de magia e seus sortilégios, tal como era previsto no art. 157 do Código Penal Republicano. E que em todo o Brasil ocorreram episódios de violência policial contra essas práticas. Ele acrescenta que:

No Pará, como na Bahia e em Pernambuco, a violência policial expressava uma espécie de projeto nacional de disciplinamento da população pobre, de origem negra e/ou indígena, existente desde o século XIX. Paralelamente à política de embranquecimento físico da população, as práticas culturais afro-brasileiras sofreram ampla perseguição com a finalidade de controle ou simples aniquilamento. As manifestações de caráter religioso não foram os únicos alvos de repressão e disciplinamento. (Leal, 2011).

Por um outro caminho para explicar o mesmo sistema de repressão e exclusão, Deus (2010) diz que "a nação brasileira assentou suas bases sob a égide do racismo antinegro e anti-indígenas". E ela acrescenta que:

Um dos papéis fundamentais do racismo tem sido negar a participação social, política e econômica a determinados grupos e tornar legítimas as diversas formas de exploração. $\mathrm{O}$ racismo está incrustado em relações de poder. Consiste na capacidade construída de um grupo em formular uma ideologia que não apenas torne legítima uma determinada relação de poder, mas, também, que funcione como um mecanismo capaz de reproduzir essa relação de poder" (Deus, 2010).

A sobrevivência das artes com identidades culturais da matriz africana na diáspora brasileira, nesse contexto de exclusão e repressão, é, sem sombra de dúvidas, 
um processo de resistência contra o racismo institucional ${ }^{5}$ que nega a participação da população negra na vida pública e no financiamento estatal, e também um processo de resistência ao racismo da sociedade brasileira.

E, ainda, temos legislação penal luso-brasileira, e brasileira, que operou por quase quatro séculos como uma política cultural de repressão e extermínio das culturas afro-brasileiras. Até 1985, a política cultural brasileira era tratada em conjunto com a educação e a saúde, somente nesse ano se desmembra a pasta para criar o Ministério da Cultura. Mas desde 1937, a participação social na Cultura era feita através de uma ‘comissão de notáveis', intelectuais oriundos das linguagens artísticas que tinham o reconhecimento de seus pares e das instituições ${ }^{6}$.

\footnotetext{
${ }^{5} \mathrm{O}$ conceito de Racismo Institucional foi definido pelos ativistas norteamericanos integrantes do grupo Panteras Negras, Stokely Carmichael e Charles Hamilton em 1967, para especificar como se manifesta o racismo nas estruturas de organização da sociedade e nas instituições. Para os autores, "trata-se da falha coletiva de uma organização em prover um serviço apropriado e profissional às pessoas por causa de sua cor, cultura ou origem étnica" Carmichael, S. e Hamilton, C. Black power: the politics of liberation in America. New York, Vintage, 1967, p. 4.

No Brasil, o Programa de Combate ao Racismo Institucional (PCRI) implementado 1 em 2005, definiu o racismo institucional como "o fracasso das instituições e organizações em prover um serviço profissional e adequado às pessoas em virtude de sua cor, cultura, origem racial ou étnica. Ele se manifesta em normas, práticas e comportamentos discriminatórios adotados no cotidiano do trabalho, os quais são resultantes do preconceito racial, uma atitude que combina estereótipos racistas, falta de atenção e ignorância. Em qualquer caso, o racismo institucional sempre coloca pessoas de grupos raciais ou étnicos discriminados em situação de desvantagem no acesso a benefícios gerados pelo Estado e por demais instituições e organizações. O PCRI é um projeto de uma parceria que contou com: a SEPPIR, o Ministério Público Federal, o Ministério da Saúde, a Organização Pan-Americana de Saúde (OPAS), e o Departamento Britânico para o Desenvolvimento Internacional e Redução da Pobreza (DFID), como agente financiador, e o Programa das Nações Unidas para o Desenvolvimento (PNUD), e teve como foco principal a saúde (CRI, 2006, p 22).

Jurema Werneck definiu o racismo institucional como "um modo de subordinar o direito e a democracia às necessidades do racismo, fazendo com que os primeiros inexistam ou existam de forma precária, diante de barreiras interpostas na vivência dos grupos e indivíduos aprisionados pelos esquemas de subordinação desse último" Werneck, Jurema. Racismo Institucional, uma abordagem conceitual, Geledés - Instituto da Mulher Negra, 2013. Ver mais em http://www.onumulheres.org.br/wp-content/uploads/2013/12/Guiadeenfrentamento-ao-racismo-institucional.pdf

${ }^{6}$ Um resumo da política pública para a cultura: 1810 - Criação do Museu Nacional de Belas Artes e Museu Histórico Nacional - As primeiras instituições culturais no Brasil se inicia com a vinda de D. João VI na transferência da corte portuguesa para o Brasil. 1938 - Conselho Nacional de Cultura - CNC criado pelo Decreto $n^{\circ} 526$ de 01 de julho, governo Getúlio Vargas para atuar no Ministério de Educação e Saúde (Ministro Capanema). 1961 - Conselho Nacional de Cultura - CNC criado pelo Decreto n ${ }^{\circ} 50.293$ de 23 de fevereiro, governo Jânio Quadros. 1985 - Ministério da Cultura - MinC, criado pelo Decreto $\mathrm{n}^{\circ}$ 91.144, 15 de março, no governo Sarney. Em 1990, governo Fernando Collor , o MinC foi transformado em Secretaria da Cultura, diretamente vinculada à Presidência da República . Essa situação foi revertida em 1992 pela Lei no 8.490, governo Itamar Franco. Em 1999, governo Fernando Henrique Cardoso, é ampliado os recursos e reestruturado segundo a Lei $\mathrm{n}^{\circ}$ 9.649. 2003 - Ministério da Cultura - MinC - Mais uma reestruturação, através do Decreto $\mathrm{n}^{\circ} 4806$, de 12 de agosto, governo Luis Inácio Lula da Silva (Lula). 2005 - Conselho Nacional de Políticas Culturais - CNPC, reestruturado pelo Decreto $\mathrm{n}^{\circ}$ 5.520, governo Lula. e finalmente com esta reestruturação, temos finalmente um colegiado de culturas afrobrasileiras no Ministério da Cultura, colegiado que só se constituí em dezembro de 2012.
} 
Ora, como as instituições e a sociedade negavam a participação da população negra, é óbvio que essa comissão era formada pela elite branca e, por que não dizer, racista, e que com essa constituição, ainda que não promovesse explicitamente o extermínio das culturas negras, simplesmente ignorava a sua existência ${ }^{7}$.

Como efeito dessa política cultura, no oitavo ano do sexto século de ocupação portuguesa na América e cento e noventa e dois anos depois da chegada da Missão Artística Francesa no Rio de Janeiro, em 06 de maio de 2008 aconteceu um evento no Forte do Presépio, no Centro Histórico de Belém, com a presença do Ministro da Cultura Gilberto Gil, da Governadora do Estado Ana Júlia Carepa e do Secretário de Cultura Edílson Moura ${ }^{8}$. A comunidade do terreiro de candomblé Mansu Nangetu participou do cortejo de culturas amazônicas que recepcionou o ministro na capital paraense. Ao fim do cortejo a comunidade foi convidada a entrar no Museu de Arte Contemporânea (que fica ao lado do Forte) para visitar uma exposição coletiva da qual o Táta Kinamboji, membro da comunidade, estava expondo seu trabalho de artista. Nesse momento a Muzenza Ndandawamaze respondeu pelo grupo: "Não, Táta! Isso não é lugar para nós!”

\section{NÓS DE ARUANDA E O DESEJO DE TRANSPOR MUROS QUE A BRANQUITUDE ERGUEU EM NOME DA EXCLUSÃO.}

\footnotetext{
${ }^{7}$ Em 2008, no Governo Lula, o MinC convidou o rapper GOG (Brasília/DF) como representante das culturas afrobrasileiras no Conselho Nacional de Política Cultural/ CNPC-MinC, em março de 2010 os delegados estaduais eleitos para a Conferencia Nacional Setorial de Culturas Afro-brasileiras elegeram Nego Lamar (Hip-hop do Maranhão, integrante do Clã Nordestino) para a mesma função. E apenas em dezembro de 2012 os delegados eleitos para o Fórum Nacional de Culturas Afro-brasileiras elegeu 15 titulares e 10 suplentes para compor o $1^{\circ}$ Colegiado de Culturas Afro-brasileiras do CNPC - MinC e este colegiado elege Arthur Leandro/ Táta Kinamboji (Artista e membro de comunidade tradicional de matriz bantu do Pará) para a representação das culturas afro-brasileiras no CNPC. Esse colegiado foi composto majoritariamente por artistas oriundos de comunidades tradicionais de terreiros de matriz africana e ao colegiado era incumbida a tarefa de construção do $1^{\circ}$ Plano Nacional Setorial de Culturas Afrobrasileiras, para isso se organizou consultas públicas e foram realizados 20 debates em 20 estados e 24 municípios brasileiros. O Plano ficou pronto em dezembro de 2014, foi protocolado na Fundação Cultural Palmares, instância do Ministério da Cultura responsável pela setorial, e desde então ignorado pelo racismo institucional na gestão cultural brasileira. Em novembro de 2015 o Fórum Nacional Setorial de Culturas Afro-brasileiras elegeu 15 titulares e 15 suplentes para compor o novo mandato do Colegiado, tendo Mestre Candieiro (Capoeira/ Paraná) como representante das culturas afro-brasileiras no CNPC, a eles é dada a tarefa de encaminhamentos para a adoção de um plano para as culturas afro-brasileiras. Ver o plano para as culturas afro-brasileiras em http://www.portalafricas.com.br/v1/wpcontent/uploads/2015/11/Plano-Setorial-para-Cultura-AfroBrasilira-paraPUBLICA\%C3\%87\%C3\%83O-EM-NOV-2015-FINAL-1.pdf

${ }^{8}$ Que, na ocasião, assinaram o termo de adesão do Pará ao Programa Mais Cultura do Governo Federal e promoveram o lançamento dos editais do programa Mais Cultura e do Edital dos Pontos de Cultura no Estado do Pará.
} 
Seria uma galeria de artes visuais um espaço de branco? E perguntamos se seria desse branco, que é um 'branco' que ao mesmo tempo dá sentido pálido à pessoa, e ao significado político da palavra? A pergunta é necessária, pois este projeto resulta numa exposição que é uma homenagem, uma celebração à memória da luta de Dona Rosa Viveiros, ou Nochê Navanakoly, ou Mãe Doca, negra mulher e maranhense de Codó, que apenas três anos após a Abolição da Escravatura enfrentou o racismo, preconceitos da época e inaugurou seu Terreiro de Tambor de Mina na capital paraense. A partir dos 18 de março de 1891 ela foi presa várias vezes porque tocava tambores e cultuava as divindades africanas com as quais preservava as tradições de matriz afro - amazônica, e nem por isso desistiu de manter aberto o terreiro que dava lugar à manutenção das tradições de sua origem negra africana. A consciência negra foi o que motivou Mãe Doca a enfrentar os desmandos da polícia e o poder constituído em alicerces racistas e discriminatórios (GEAM/NEAB - UFPA, 2013).

Aruanda é uma referência ao porto de São Paulo de Luanda, capital de Angola e lugar de onde partiam os negros sequestrados e trazidos ao Brasil na condição de escravos, e a referência ficou na memória coletiva como o lugar onde se encontraria novamente a liberdade que vinha com as lembranças do continente de origem.

Luanda, Aluanda, Aruanda, o Tempo, que é divindade na matriz bantu que povoa Angola do mesmo porto de Luanda, muda a palavra e muda também a semântica. E, saindo de uma referência geopolítica, Aruanda persiste hoje no imaginário afrobrasileiro como o lugar da liberdade, um paraíso que habita cantigas de brincadeiras de roda, jogos de capoeira, rezas e cantos religiosos, as manifestações de cultura popular e outras situações em que os povos negros têm importância na construção da paisagem e do lugar.

"Nós de Aruanda - artistas de terreiro" "9 dá título para um projeto e uma exposição que brinca com os sentidos que essa expressão pode ter: de quem, ou de quais

9 Sobre o projeto/exposição: A primeira versão da exposição "Nós de Aruanda - artistas de terreiro" foi em 2013 e dela participaram, artistas: Alan Patrick Fonseca/ Pejigan Oba Gankona; Alex Leovan/ Táta Dianvula; Arthur Leandro/ Táta Kinamboji (e rede[aparelho]-:); Coletivo Abebê (Samantha Silva e Tatyane Silva); Dellean Cardoso/ Táta Kitauanje; Deyze Mello; Duda Souza; Edson Catendê e Grupo Bambarê; Élida Neves; Firmo Leite/ Táta Mukundemim; Jurema de Manezinho; Mametu Kátia Hadad; Mametu Nangetu; Maurício Franco; Rodrigo Ethnos/ Táta Kafungeji; Ya Rita Gedeunsu e Lucas Tungenan (Tereiro T.E.U.C.Y); e Ysa Motta. Pesquisadores: Alef Monteiro; Amadeu de Deus; Isabela do Lago; Jocimara Alves; Lorena Alves; Marilu Campelo; Raimundo Jorge de Jesus; Renata Silva da Costa; Shirley Muryel; Simone Araujo e Zélia Amador. Em 2014 participaram:AFAIA e Grupo Bambaré - Ilê Axé Iyá Omi Ofá Kare/// Bia Cabral - Casa de Umbanda Ogum Beira-Mar e Mamãe Oxum/// Babá Kyssudã (Natanael Faro) - Ilê Ase Oyá Mesen/// Babá Tayandô (Luiz Loureiro Cunha) - Seara de Umbanda Ogum Beira-Mar/// Carlos Vera Cruz - Mansu Nangetu/// Cézar de Ogum - Terreiro Casa de Ogum e Yemanja/// Coletivo Corpo Sincrético - Ilê Asé Omindê/// Duda Souza - Terreiro de Mina do Caboco Pena Verde/// Eleanor Palhano - Ilê Asé Agaronilê/// Ekedy Janete Oliveira - Seara de Umbanda de Pena Verde/// Emanuela Karina Lisboa - Abassá AfroBrasileiro Konzenzala de Kafungê/// Isabela do Lago - Mansu Nangetu/// Katia Jurema - Terreiro de Pai Caduca/// Kpejigan Alan P. da C. Fonseca -

Revista da ABPN • v. 11, n. $27 \cdot$ nov 2018 - fev 2019, p.113-138 
de nós, nós estamos falando? Quem somos nós? É uma articulação entre pesquisadores das tradições Afro-amazônicas com artistas pertencentes a comunidades de terreiros de povos tradicionais de matriz africana com objetivo de realizar exposições anuais com obras de artistas de terreiros.

Pode ser que agora, no século XXI, tanto a capital paraense quanto o 'mundo das artes visuais' sejam sim um espaço legítimo de ocupação do 'negrume' amazônida, mas também é latente que, assim como são os terreiros nos espaços públicos, ainda é invisível a produção artística paraense que coloque em evidência as questões sócioculturais desse mesmo "ser afro-amazônico".

A necessidade de inserção dos artistas de terreiros no circuito de artes visuais, tanto veio desse incômodo da recusa da comunidade em adentrar o espaço do museu de arte em que o artista/ professor/ membro de comunidade estava expondo, quanto é fruto de uma outra situação de aula que surgiu no final de 2011, como um "insight" durante as aulas da disciplina "Poéticas Afro-amazônicas" para o curso de especialização em Saberes africanos a afro-brasileiros na Amazônia, ofertado pelo Grupo de Estudos AfroAmazônicos — GEAM/ UFPA.

Foi durante essas aulas, ministradas por três professores: Arthur Leandro, Zélia Amador de Deujs e Bruno B. O., em que tínhamos o objetivo de subsidiar o ensino de arte e cultura afro-brasileiras e contribuir com a implantação da Lei 10.639/2003, que se percebeu que a maioria das obras que a história da arte registra como "arte afrobrasileira" são produções de artistas euro-descendentes que abordam questões da religiosidade afro-brasileira, algumas vezes sem mesmo fazer parte de comunidades

Fundere Oya Jokolosy/// Lucivaldo Sena - Mansu Nangetu/// Mc Bruno B.O - Mansu Nangetu/// Mam'etu Muagilê (Elizabeth Leite Pantoja) - Rudembo Nagunzo ti Baburucema/// Mam'etu Nangetu (Oneide Monteiro Rodrigues) - Mansu Nangetu/// Nazaré Cruz - Ilê Iyaba Omi/// Ndanda Kalamin (Aisha Silva) Mansu Nangetu/// N'ganga Makala (Cristiane Costa) - Mansu Nangetu/// Ogã Valter Vieira - Ilê Asé Agaronilê/// Pereira - Ilê Axé Baba Abuque/// Samantha Raissa - Tenda Espírita de Umbanda Cabocla Yacira/// Sttefane da C. Trindade- Fundere Oya Jokolosy/// Stéfano Paixão - Rudembo Nagunzo ti Baburucema/// Tata Kafunlumizô (Ângelo Imbiriba) - Inzo d"Angola Lua Branca/// Tata Djanvula (Aléx Leovan) - Mansu Nangetu/// Tata Kafungueji (Rodrigo Barros) - Rudembo Ngunzo ti Baburucema/// Tata Kinamboji (Arthur Leandro) - Mansu Nangetu/// Vodunsiahè Murilo Miranda - Fundere Oya Jokolosy/// Vodunsiahè Fernando Sarmento - Fundere Oya Jokolosy/// Yá Tundê (Edivânia) - Ilê Asé Agaronilê/// Ysa Motta - Rudembo Nagunzo ti Baburucema/// Zezinho do Mocambo - Terreiro do Pai Loroji Apoio/ Parcerias: Grupo de Estudos Afro-Amazônico - GEAM//// Casa Brasil- África//// Faculdade de Ciências Sociais - FCS//// Faculdade de Artes Visuais e Museologia - FAV//// Instituto de Filosofia e Ciências Humanas - IFCH//// Instituto de Ciências da Arte//// Assessoria de Diversidade Étnico- Racial//// Grupo de Estudo e Pesquisa em Educação do Campo na Amazônia/ GEPERUAZ - ICED//// Universidade Federal do Pará - UFPA//// Secretaria de Estado da Cultura - SECULT - PA//// Fundação Cultura do Pará Tancredo Neves - FCPTN//// Galeria Theodoro Braga - GTB//// Comunidades de Terreiros. 
tradicionais de matrizes africanas, e, ao fim, o que percebemos, é que dentre eles é fácil de encontrar o olhar preconceituoso sobre as práticas tradicionais afro-brasileiras.

Ao invés do uso da religiosidade apenas como temática e apropriação cultural, o projeto Nós de Aruanda, artistas de terreiro aponta para a diretriz da produção de poéticas visuais com protagonismo, envolvimento e aprofundamento das tradições do sagrado africano na diáspora brasileira.

A questão é que percebemos é que as artes visuais parecem um campo fechado de uso restrito das camadas mais abastadas da sociedade - um mundo restrito às elites. Essa percepção estimulou o Grupo de Estudos e Pesquisa Roda de Axé a iniciar o mapeamento da produção artística nas comunidades de terreiros, e nessa pesquisa encontramos vários artistas que estão no processo de inserção e legitimação no circuito das artes visuais. A proposta que o grupo apresentou aos artistas foi de reunir todos eles / nós13 em um esforço coletivo de realização de uma exposição em homenagem à Mãe Doca, em que se pudesse apresentar a diversidade dessa produção "periférica" como um discurso afirmativo do protagonismo afro-amazônico na produção de poéticas visuais,

A primeira versão da exposição só foi possível porque a gerente da Galeria Theodoro Braga, da Fundação Cultural do Pará, que naquela época era Eliane Moura, era parte de uma comunidade de terreiro. Tata Kinamboji, um dos organizadores da exposição, chegou a ela e disse: "Eu não tenho nada a não ser uma ideia. Não tenho porta-fólio, não tenho uma relação com nomes de artistas, nada! É de macumbeiro pra macumbeiro, eu preciso de espaço na galeria pra fazer uma exposição...”. Eliane mostrou os caminhos das pedras para ocupação da galeria no mês de março, um mês que não entrava no calendário de pautas da GTB, e o argumento foi institucional - é projeto do GEAM/ UFPA.

A exposição abriu em 8 de março de 2013 na Galeria Theodoro Braga da Fundação Cultural do Pará Tancredo Neves/ GTB-FCPTN/ Governo do Pará, e reuniu cerca de 20 artistas visuais pertencentes a comunidades de povos tradicionais de terreiros de matriz africana em Belém, Ananindeua, Marituba e Castanhal no Estado do Pará.

Já em 2014, o que se revelou nesta coletiva foram práticas artísticas do cotidiano das culturas da diáspora que recriam algumas dessas diversas Áfricas amazônicas, os trabalhos apontam para a pluralidade de entendimentos sobre a arte e em comum trazem 
um forte viés emotivo baseado na coletividade, no cotidiano dos terreiros, nas lutas políticas por direitos de cidadania, na política afirmativa, nas práticas ritualísticas, na memória afetiva e na memória de vida como elementos essenciais para a construção de mundo que resulta na poética desses artistas.

A segunda versão foi realizada como projeto de exposição aprovado em edital de pauta da GTB/FCPTN, e abriu no dia 7 de março com cerca de cinquenta artistas no elenco da exposição com direito a publicação de catálogo e coquetel aos convidados presentes na abertura. O edital 001/13-FCPTN, de ocupação de pauta da GTB/FCPTN para o ano de 2014, e no mano seguinte a GTB já tinha o período de março como opção para exposições, e esta mudança talvez seja fruto da experiência da primeira versão da Nós de Aruanda.

Em 2015, a terceira versão da exposição foi abrigada no "Canto do patrimônio" - Galeria de exposições do IPHAN-PA, no mês de maio. Como desdobramentos da Nós de Aruanda, em 2015 também temos:

1. O desfile da Embaixada de Samba do Império Pedreirense com o enredo: $A$ coroa do império no batuque da Pedreira, de Tata Kinamboji, na Aldeia Cabana (sambódromo de Belém) em fevereiro;

2. A performance Padê Urbe, de Carlos Vera Cruz (Mansu Nangetu), na comissão de frente da Embaixada de Samba do Império Pedreirense;

2. O artista Mauricio Franco (Terreiro de Umbanda de Nossa Senhora da Conceição) ocupando a Galeria do Centro Cultural do Carmo, no mês de março, com a exposição Recantos;

3. A comunidade do Terreiro Mansu Nangetu com o Projeto Kiuá Nangetu Poéticas visuais de resistência negra, com vivências, performances e intervenções em espaços públicos de Belém de março a maio;

4. A exposição Reminiscências de Nzinga com instalações da coletividade da comunidade do Mansu Nangetu na Galeria Theodoro Braga no mês de maio;

5. A exposição Ferramentas, de Jean Ribeiro (Hùkpame Otolu Na Hem Xwe), na Galeria Theodoro Braga em setembro;

6. A exposição No trajeto das águas, sobre o sulco dos rios, de Glauce Santos (Hùkpame Otolu Na Hem Xwe) no Museu de Arte Contemporânea do Pará (Casa das 11 janelas), em dezembro; 
7. A imagem da escultura Nkosi, de Rodrigo Ethnos (Táta Kafungeji Rundembo Ngunzo ti Bamburucema), como capa do livro Segurança Pública e Justiça: Direitos Humanos na Amazônia, editado pela SDDH - Sociedade Paraense de Defesa dos Direitos Humanos, em dezembro.

\section{É CHEGADA A HORA DE TIRAR NOSSA NAÇÃO DAS TREVAS DA INJUSTIÇA RACIAL ${ }^{10}$}

$\mathrm{Na}$ abertura da $1^{\circ}$ versão da exposição Nós de Aruanda, o que mais se ouviu nas conversas e discursos foi:

— Eu não sabia que eu era artista!

Essa negação do ser artista é resultado da absorção de um modelo euronormatizado de artista e de obra de arte. Vale ressaltar que uma das maiores dificuldades em realizar a curadoria para as três primeiras edições da exposição coletiva foi justamente convencer os/as artistas de terreiro de que aquilo que eles/elas fazem cotidianamente no exercício de suas diversas práticas tradicionais é arte! Pois, é nos domínios mais profundos da subjetividade que se alicerçam as discriminações e delimitações de espaço "cordialmente" estabelecidas na sociedade brasileira, e mesmo entre nós, ainda persiste a ideia de que 'arte' é apenas a arte de origem eurocêntrica.

Ou seja, esse modelo de artista que é legitimado pelo sistema da arte não compreende as obras cotidianas produzidas dentro das comunidades tradicionais de terreiros de matriz africana. E essas práticas não fazem parte dos méritos estéticos abordados pela doxa curatorial dos salões de arte, em um circuito que reforça padrões estético-burocráticos euronormativos desse nicho adotado como a única voz da verdade que dita tendências a serem seguidas até que "um alguém" se legitime com o status de artista visual.

Preteridos e preteridas desse sistema sufocante, Nós de Aruanda, os que até então eram "ninguéns" das artes visuais, ocupamos espaços importantes para seguir com outras formas de resistência para a nossa lógica de visualidade.

É preciso evidenciar que, apesar da suposta ausência de negros na Amazônia, $76,7 \%$ dos paraenses se auto-declararam pretos ou pardos no censo demográfico de

\footnotetext{
${ }^{10}$ Frase atribuída à Zumbi dos Palmares. Disponível em http://pensador.uol.com.br/autor/zumbi_dos_palmares/ consultado em 20 de dezembro de 2015.
} 
$2016^{11}$. No Pará, existem 161 comunidades quilombolas tituladas e 362 certificadas $^{12}$. Pelas estatísticas do IBGE, o Pará é, atualmente, o estado com maior população negra no Brasil.

Essa presença maciça de negros na população também significa que o racismo institucional é latente, e por isso o mundo negro nas artes visuais também evidencia o conflito étnico racial e o estranhamento em relação ao lugar das artes visuais e a sua rede de legitimação por parte dos artistas de terreiro, esse estranhamento evidenciado pela Muzenza Ndandawamaze quando do convite para visitar o Museu de Arte Contemporânea. É facilmente percebido em entrevistas com autoridades de Matriz africana e nos discursos daqueles que vivem na fronteira entre os mundos das comunidades tradicionais de terreiro e o mundo eurocêntrico imposto para as artes visuais.

Sobre o apagamento das origens na África negra, Samantha Silva (2014) conta que o Terreiro em que sua mãe era iniciada era vizinho da casa de sua avó, quase que uma extensão de sua casa. Ela começa falando de sua memória afetiva dos tempos de infância, e que ela ficava encantada com o colorido das roupas, dos acessórios, a decoração do ambiente e tudo o mais o que via naquele lugar, mas que ao entrar no curso de artes visuais da $\mathrm{UFPA}^{13}$ ela se afastou do terreiro "e aí nesse período de separação, de tempo, de não frequentar, é que eu estou na universidade. E nesse período essas questões passavam pela minha cabeça, mas eu não via nenhuma forma como eu poderia trabalhar com isso". O dilema pelo qual ela passou talvez seja o mesmo dilema de todos os estudantes negros em qualquer nível de ensino, a negação de qualquer possibilidade de humanidade na herança africana.

\footnotetext{
11 O IBGE considera as influências da ideologia do embranquecimento para a análise dos censos no Brasil, por isso, para definir o percentual da população negra brasileira é considerada a somatória da auto declaração de pretos e pardos, conforme disposto no Estatuto da Igualdade Racial.

12 Ao todo, no Brasil, são um pouco mais de 3800 comunidades quilombolas certificadas como tal, o que significa dizer que aproximadamente $10 \%$ das comunidades quilombolas do Brasil se localizam no Estado do Pará que, em número de quilombos, fica atrás, apenas, da Bahia e do Maranhão. Sobre as comunidades quilombolas ver http://www.palmares.gov.br/?page_id=88\&estado=PA Consultado em 29 de dezembro de 2015. E sobre as comunidades quilombolas certificadas ver http://www.palmares.gov.br/wpcontent/uploads/crqs/lista-das-crqs-certificadas-ate-23-02-2015.pdf Consultado em 29 de dezembro de 2015

${ }^{13}$ A universidade é um dos principais agentes legitimadores da euronormatividade nas artes, e quando membros de terreiros adentram o curso de artes visuais a tendência é o esquecimento de suas raízes para poderem pensar em inserção no circuito profissional.
} 
Samantha conta que tinha receio de levar para a faculdade a sua experiência em terreiro. Ela diz: "no período da faculdade eu tive contato com vários artistas, várias estéticas que não eram estéticas que passavam pelo universo afro-brasileiro ou afroreligioso, enfim, qualquer contato que estivesse voltado para essas questões". Acrescenta que antes de participar do projeto ela não percebia "não sabia por que caminho poderia conectar, porque eu não via, não via de que forma isso poderia entrar (...), se isso era visto como arte ou não, porque se não está na academia então não é arte". Em outras palavras, a instituição de ensino a legitimar a hegemonia do colonizador e a massacrar as identidades afro-amazônicas. Com a Nós de Aruanda, Samantha afirma: "Eu me descobri negra, descobri tudo isso que o terreiro traz, tudo isso que a cultura africana traz (...) eu sentia, percebia, mas não tinha conectado (...) eu tinha visto não havia olhado pra dimensão dessas coisas, pras poéticas afro-brasileiras, pra religiosidade..."14

Se o ensino de artes desconectado da cultura e da experiência da vida na 'Amazônia Negra', provoca o afastamento de Samantha das suas raízes, por outro lado Rodrigo Ethnos (2015) trilha um caminho diferente, ele rejeita a universidade e parte para um outro tipo de formação:

...então quando fui para a universidade achei que o curso de Artes Plásticas me tornaria artista. Me enganei profundamente (risos), mas minha inserção na graduação contribuiu muito para minha formação, mostrando exatamente o tipo de artista que eu não queria ser. Foi aí que eu conheci a capoeira angola, e a capoeira me levou para uma casa de candomblé e para uma casa de carimbó.

Me formei sem nunca ter participado de exposições individuais ou coletivas. Meu coração sempre bateu mais forte por outro tipo de arte, a capoeira, o batuque, rodas de rua, carimbós, candomblés... ${ }^{15}$

Mametu Nangetu (2015) não frequentou cursos de arte em universidades, mas tinha a percepção de que "pra ser artista precisava primeiro passar pela academia, ou ter um pai artista que ensinasse o seu filho, e [agora] eu vejo que isso também é um dom

\footnotetext{
${ }^{14}$ Silva, Samantha. Artistas de Aruanda. Entrevistadores: Tata Kinamboji (Arthur Leandro), Luah Sampaio, Luiza Cabral e Vitor Gonçalves. Belém 10 de junho de 2014. Entrevista concedida para o Programa 'Nós de Aruanda' para a 'WebTV Azuelar' - PROEX/UFPA, para a construção de um documentário sobre a exposição Nós de Aruanda.

${ }^{15}$ Ethnos, Rodrigo. Nkosi - escultura monumento. Entrevistadores: Equipe do Projeto Azuelar. Belém, 20 de maio de 2015nb. In Leandro, Arthur. Lago, Isabela \& Rodrigues, Oneide Monteiro. Kiuá Nangetu poéticas visuais de resistência negra. Belém: Instituto Nangetu. 2015, p 46.
} 
dos nossos deuses" ${ }^{\text {"16 }}$. A percepção de Mametu Nangetu, é traduzida por Rodrigo Ethnos (apud Barros e Pinheiro, 2015) como uma fronteira entre matrizes bem distintas:

Aqui é o espaço do branco, cara. É o espaço que o branco determinou pra ser arte. Mas isso é uma coisa pequena, porque tudo ai fora é universo de arte. Aqui é onde eles querem que a arte seja cultuada.

(...) eu sempre achei a arte de galeria uma coisa morta. Nunca me identifiquei. Entrava naquele espaço e já não me identificava com aquele formato, com aquilo tudo ali. Nunca me identifiquei. Entrando no curso de artes visuais, as relações que permeiam, como é que se diz, por trás das cortinas, é muito mais escroto ainda, sabe? Então, eu nunca percebi vida nisso, até aqui... ${ }^{17}$

Joana Machado participou da terceira edição da Nós de Aruanda com uma performance com narrativas de histórias míticas de Orixás. Ela diz que se integrou ao projeto por ser bastante aberto, e conta que foi como espectadora na primeira versão da exposição, que foi levar seus alunos e viu que as pessoas colocaram o seu corpo, a sua linguagem, pra fora, e que como é um projeto de comunidades de terreiro, nós que somos de terreiro, a gente vem integrando no que consideramos o nosso corpo artístico: "Se tu perguntares, eu não sei tecer, não sei bordar, não sei..., mas eu sei falar! Minha arte é minha fala, minha arte é minha memória”. (Machado, 2015). Sobre a galeria, Joana Machado (2015) é categórica ao afirmar que "a exposição foi na "Galeria Theodoro Braga, historicamente um espaço que não foi feito pra nós exatamente... foi feito pra todos, mas nós nunca estivemos dentro" ${ }^{18}$.

Se Joana tem a consciência de que o espaço não foi feito para nós, ela também percebe que essa ausência é provocada pelos processos de hegemonia cultural em séculos de uma sociedade fundada no racismo ao dizer do seu estranhamento ao ter ouvido Mãe Beth falar que não sabia era artista. A percepção de Joana leva à reflexão da produção artística pela matriz cultural africana, ela diz: "se você entrar na casa de Mãe Beth, você diz que ela é curadora de um grande acervo de obra de arte, porque lá

16 Mametu Nangetu, Roda de conversa com Glauce Santos, Jean Ribeiro e Mametu Nangetu. Entrevistador: Arthur Leandro. Belém, 1 de maio de 2015a. Entrevista concedida para o Programa "Nós de Aruanda na webTV Azuelar. Disponível em https://www.youtube.com/watch?v=3wbQ8_iN5XA consultado em 28 de dezembro de 2015.

17 Ethnos, Rodrigo. Exposição Nós de Aruanda - Artistas de terreiro. Entrevistadora: Tainara Pinheiro. Belém, 29 de maio de 2015b. Entrevista concedida ao Projeto Nós de Aruanda, artistas de terreiro/ GEAM - UFPA.

18 Machado, Joana Carmem Nascimento. Roda de conversa com a artista Joana Carmem Machado contação de estórias afro-brasileiras. Entrevistadora: Luiza Soares Cabral Belém: Projeto Azuelar, Instituto Nangetu, 18 de abril de 2015. Entrevista concedida ao Programa "Nós de Aruanda na webTV Azuelar". 22 min. Disponível em $<$ https://www.youtube.com/watch?v=qmXr9GfWy4g $>$ Acesso em 24 de dezembro de 2015 
ela tem a mãozinha dela talhada naquele mariô, que fica ali na porta", e conclui com a afirmação da necessidade da afirmação da matriz quando afirma que "é o que não está estabelecido como arte e, subvertendo a ordem..., nós não estávamos estabelecidos e agora vamos nos tornar estabelecidos, nós vamos nos estabelecer, estabelecer como $\operatorname{arte}^{\prime 19}$.

Nesse mesmo caminho de afirmar a visualidade afro-amazônica, Mametu Nangetu (2015) declara que "antes eu nunca tinha me visto como artista, não entendia esse mundo. Demorei para entender que nossa cultura é uma arte; até uma folha no chão tem uma representação para a gente" ${ }^{, 20}$.

Para Duda Souza (apud Barros; Pinheiro, 2015) “isso aqui nada mais é do que uma forma da gente se juntar, se aproximar, se conhecer e através da arte melhor ainda! Porque quem dá esse olhar artístico, quem olha com arte, quem dá esse olhar artístico para as nossas coisas, somos nós mesmos" 21 , Duda ainda acrescenta que "não é o outro, o branco, (...) que vem de fora e diz: olha isso aqui feito com traçado tal, com aquarela tal, com a linha tal. Somos nós que temos um olhar poético sobre as nossas coisas, que é isso que é singular, que eu acho peculiar nessa exposição".

\section{ARTE ARUANDA, A VISUALIDADE NA RODA DO GIRAMUNDO}

São os próprios artistas que apontam caminhos para a tentativa de compreender a visualidade afro-amazônica e a resistência da matriz cultural africana. É o cotidiano na cultura tradicional de matriz africana que dá o suporte da produção artística, uma produção poética estreitamente relacionada com as histórias de vida.

$\mathrm{Na} 1^{\mathrm{a}}$ exposição Nós de Aruanda, Mametu Nangetu apresentou a instalação "Pretinhos, minha família", e sobre esse trabalho, ela conta:

E eu vejo que isso também é um dom dos nossos deuses, que nos dá a sabedoria, tanto com as mãos, de manusear o que a gente quer, mas também a intuição. (...) Eu tenho a intuição, nós temos a intuição de fazer um trabalho e um trabalho que o público reconheça como arte, que ainda tem isso, né? Quando eu olho aqueles bonecos (...) eu vi que o meu ancestral que me deu esse

\footnotetext{
${ }^{19}$ Idem.

${ }^{20}$ Mametu Nangetu. Fundamento - intervenção poética de Mametu Nangetu. Entrevistadores: Equipe do Projeto Azuelar, Belém maio de 2015b. In Leandro, Arthur; Lago, Isabela \& Rodrigues, Oneide Monteiro. Kiuá Nangetu - poéticas visuais de resistência negra. Belém: Instituto Nangetu. 2015, p 53.

${ }^{21}$ Sousa, Eduarda. Exposição Nós de Aruanda - Artistas de terreiro. Entrevistadora: Tainara Pinheiro. Belém, 29 de maio de 2015. Entrevista concedida ao Projeto Nós de Aruanda, artistas de terreiro/ GEAM - UFPA.
} 
dom e que me mostrou essa família que eu tenho, sempre mostrou essa família (que pode ser invisível pra vocês, mas que faz parte da minha vida), faz parte do meu ancestral. (...) eu via aquilo como espíritos, como visagem, e depois eu vim a entender que aquilo fazia parte da minha história, que aquelas pessoas eram a minha história. (...) Eu sempre, criança, eu sempre fazia aqueles bonecos de pano, né?! Eu tive uma infância muito pobre e na minha época as bonecas eram tudo de pano, tudo preta de cabelo pixaim, e aquilo era uma arte, né? Minha avó ensinava a gente a fazer aqueles bonecos, e fazia parte da minha vida, a ancestralidade negra. (Mametu Nangetu 2015a) ${ }^{22}$.

Rodrigo Ethnos declara que "há muito todo mudo já sabia que tudo que a gente faz no terreiro é artístico", e relata seu processo artístico dizendo que:

Minha prática artística já é minha cultura religiosa, é o terreiro, (...) Trocamos ideias sobre vontades e, juntos, fazemos. (...) Minha arte é meu cotidiano, é a luta do lado dos meus irmãos afro religiosos, é a luta das mulheres, dos homoafetivos, dos trabalhadores. A arte é revolução, transformação. É neste sentido que eu produzo, para suscitar pensamentos, atitudes para um mundo mais igualitário, mais humano. O que mais me move a produzir é o amor! Produzimos, estas exposições, porque nos amamos, acreditamos um no outro, amamos nossas divindades, nossa cultura, e produzimos para mostrarmos que estamos vivos e para que não sejamos massacrados (Ethnos apud Barros e Pinheiro, 2015).

Nesse caminho da resistência contra o massacre cultural da hegemonia eurocêntrica, Táta Kinamboji (2015) explica que:

... toda a minha participação no projeto "Nós de Aruanda, artistas de terreiro" aponta para essa vontade, para a tentativa de dar visibilidade a presença dessa população na cidade de Belém. Na primeira exposição do "Nós de Aruanda", em 2013, a minha proposição foi a troca do nome do elevado da avenida Júlio César, a Câmara de Vereadores de Belém havia colocado o nome de um pastor, juntamos a comunidade e fomos lá e num ritual sagrado, poético e político, nós rebatizamos tudo para "Exu de Mãe Celina", reafirmando aquele lugar como espaço onde Mãe Celina dava grandes festejos, que é mais uma das histórias das comunidades de terreiro que a institucionalidade da cidade tenta invisibilizar. No ano seguinte, também na exposição Nós de Aruanda, propus a construção de um monumento em homenagem à Mãe Doca, na esquina da Travessa Humaitá com a avenida Duque de Caxias, no Marco. E para comprovar a necessidade de se discutir o racismo, a intolerância religiosa, naquele mesmo dia, apenas seis horas após nossa intervenção, o monumento foi criminosamente derrubado ${ }^{23}$. (Tata Kinamboji, 2015)

\footnotetext{
22 Mametu Nangetu, Roda de conversa com Glauce Santos, Jean Ribeiro e Mametu Nangetu. Entrevistador: Arthur Leandro. Belém, 1 de maio de 2015a. Entrevista concedida para o Programa "Nós de Aruanda na webTV Azuelar. Disponível em https://www.youtube.com/watch?v=3wbQ8_iN5XA consultado em 28 de dezembro de 2015

${ }^{23}$ Tata Kinamboji. As mata tem morado! Obra invisível para população invisível/ espectador específico Totem monumento erguido na Mata da CEASA. Entrevistadores: Equipe do Projeto Azuelar. In Leandro, Arthur. Lago, Isabela \& Rodrigues, Oneide Monteiro. Kiuá Nangetu - poéticas visuais de resistência
} 


\section{RENEGRIR! OU POÉTICAS DA RESISTÊNCIA NEGRA}

Para nós, arte é campo de batalha na guerra simbólica, Táta Kafungeji (Rodrigo Ethnos)

Estamos a falar do complexo sistema de exclusão/inclusão da arte com o protagonismo de comunidades tradicionais de matriz africana. E somos, sim, artistas/pesquisadores/adeptos e membros de comunidades tradicionais que preservam as tradições africanas na diáspora brasileira, motivo pelo qual nos imputamos a responsabilidade de desnudar as máscaras do racismo e ir além daquilo "que se queira mostrar" habitualmente, ou que é difundido por uma falsa democracia racial. Com tudo isso, colocamos em xeque o modelo de arte e de artista calcado pelo sistema de arte vigente, sistema que é discursado como um canto uníssono entre galerias, museus, curadores, escolas de formação artística e universidades, sistema rodeado por salões e galerias do circuito (dito) oficial, devidamente localizado nos bairros centrais da capital do Pará.

Durante a construção da Nós de Aruanda ficou evidente que o projeto confrontava realidades muito distantes entre esse panorama do circuito das artes visuais já legitimado e instituído e as práticas poéticas de matriz africanas na Amazônia, e o confronto, o conflito de propostas, criou muitas dificuldades em estabelecer parcerias, tanto com instituições de apoio/patrocínio, quanto com instituições de ensino escolar para realizar atividades educativas previstas pelo projeto como mecanismo de atender os pressupostos da Lei $\mathrm{N}^{\circ} 10.639 / 2003$.

Pensar a Nós de Aruanda é pensar no reflexo do racismo na sociedade brasileira. As ideologias racistas são abrangentes na medida em que o racismo também é abrangente; na vida cotidiana, ele não aparece mais como um corpo estrangeiro, identificável, chegando a ser fácil negar a sua existência. No seu ponto mais alto de sucesso evolutivo, o racismo, como forma de consciência grupal, não aparece mais como racismo e, até mesmo, se nega como tal. É essa característica de poder se "negar a si mesmo" que lhe confere tal plasticidade e resistência aos esforços de mudança. (Moore, 2007, p. 257)

negra. Belém: Instituto Nangetu. 2015, p 35 
Pensar essas máscaras racistas nos ajuda a visualizar o funcionamento e as demarcações segregacionistas da sociedade como um todo, ao mesmo tempo em que nós, artistas e educadores, precisamos enxergar que podemos ser atraídos e absorvidos por essas estratégias ao ponto de tomar posicionamentos racistas e perpetuar as práticas euronormativas que a história da arte nos ensina desde as séries iniciais até a vida universitária, num aprendizado contínuo de negarmos a nós mesmos, como explica Moore (2007). Encontramos, portanto, o risco da posição cômoda de seguir carregando essa máscara da falsa democracia racial, e ao mesmo tempo o medo angustioso de nos surpreendermos carregando essa máscara.

Diante disso tudo, nós, da Nós de Aruanda, nos voltamos para a resistência cultural em busca de uma desobediência epistemológica, que nós, de comunidades de terreiro, já adotamos há muito e que é o motivo pelo qual asseguramos nossa existência em solo brasileiro. Pois a cultura e filosofia de matriz africana, que fundamentam nossas tradições e nossa religiosidade, não se objetivam na peça artística e nem esta é uma mera função do religioso; estamos interagindo com "linguagens diferentes que expressam planos complementares de significados, ou seja, são fatos sociais estéticoreligiosos.” (Silva, 2008, p. 99)

O que comumente ocorre é uma classificação de nossas manifestações estéticoreligiosas como símbolos de um mundo pré-moderno, primitivo, exótico e fetichista comumente estigmatizado e interdito junto a modernidade e a valorização unilateral de movimentos artísticos, acadêmicos ou não, e suas hegemonias recaindo sobre o erro da visão folclorizante do exotismo que não compactuam com os objetivos principais de Nós de Aruanda.

Apesar de termos à nossa disposição todo um marco legal que compreende tanto os meandros da política cultural de governo ${ }^{24}$, quanto toda uma reformulação de diretrizes nas bases na educação, quando propomos um trabalho que assume a identidade negra, encontramos barreiras ideológicas que simplesmente negam nossos direitos de expressão e, com isso, nos revelam a falsa democracia racial em que

\footnotetext{
${ }^{24}$ Por exemplo, apesar da Lei 10.639/03 aparecer nas diretrizes do Plano Nacional de Cultura (2010), em nenhuma meta desse mesmo plano (das publicadas em 2011) aparecem as palavras 'afro' 'negra' ou qualquer outra referência que localize a origem na África negra. MINC. Metas do Plano Nacional de Cultura. Brasília, MinC. Dezembro de 2011. Disponível em http://www.cultura.gov.br/documents/10883/11294/METAS_PNC_final.pdf/ consultado em 31 de
} dezembro de 2015. 
vivemos. E não podemos nos esquecer que, toda ideologia da desigualdade racial plantada no seio de nossa sociedade, é uma ideologia baseada no ódio, e, portanto, no desejo de silenciamento, de rebaixamento, de exclusão, de invisibilidade, e, portanto, de extermínio.

O tamanho do universo afro-amazônico é similar ao tamanho de nossa incapacidade de conhecer toda essa diversidade, mas mesmo que saibamos da impossibilidade de abarcar o todo, a proposta deste projeto e desta exposição é renegrir $^{25}$, renegrir no sentido de dotar a arte novamente da dignidade negra, reterritorializar a arte como lugar de tradição negra africana... RETORNO da visualidade poética amazônica à origem africana.

\section{REFERÊNCIAS}

\section{Livros}

FANON, Franz. Pele negra máscaras brancas. Tradução de Renato da Silveira. Salvador: EDUFBA, 2008.

FUNARTE (Org.). As artes visuais na Amazônia, reflexões sobre uma visualidade regional. Rio de Janeiro: FUNARTE; Belém: SEMEC. 1985.

GUIBERNAU, Berdun; MONTSERRAT, Maria. Nacionalismos: o estado nacional e o nacionalismo no século XX. Tradução de Mauro Gama e Claudia Martinelli Gama. Rio de Janeiro: Jorge Zahar Ed., 1997.

HOLANDA, Sérgio Buarque de. Raízes do Brasil. São Paulo: Companhia das Letras, 1995.

LANDES, Ruth, A cidade das mulheres, Rio de Janeiro: Editora da UFRJ, 2002.

LEANDRO, Arthur. LAGO, Isabela \& RODRIGUES, Oneide Monteiro. Kiuá Nangetu poéticas visuais de resistência negra. Belém: Instituto Nangetu. 2015

LEANDRO, Arthur; DO LAGO, ISABELA. Arte-Aruanda: o desejo de transpor os muros do mundo euronormativo no circuito de artes visuais. In: SANTOS, Marcio Antonio Raiol dos. COELHO, Marinilce Oliveira \& SANTOS, Francisco Ewerton Almeida dos. (Org.). Cadernos de Ensino: Africanidades. 1ed.Belém: Editora Açaí/Escola de Aplicação - UFPA, 2015.

MOORE, Carlos. Racismo e Sociedade: novas bases epistemológicas para entender o racismo. Belo Horizonte: Mazza Edições, 2007.

25 Como antídoto para o denegrir! Africanizar é, por exemplo, negar a imagem ibérica e afirmar a imagem de mulher negra ao se falar de Iemanjá. Por isso eu usei o neologismo RENEGRIR, renegrir em contraposição do denegrir (que o dicionário diz ser reduzir [rebaixar] a condição de negro) - denegrir de.ne.grir , (de2+negro+ir) vtd e vpr 1 Tornar(-se) negro ou escuro: As chamas denegriram a parede. A sua pele denegriu-se. vtd 2 Macular, manchar, infamar: Ninguém o denegrirá na minha presença. Denegriu-lhe a reputação com palavras aleivosas. vpr 3 Pint Escurecer-se. Significado de 'denegrir' http://michaelis.uol.com.br/moderno/portugues/index.php?lingua=portuguesportugues\&palavra=denegrir 
MUNANGA, Kabengele. Rediscutindo a mestiçagem no Brasil: identidade nacional versus identidade negra. Petrópolis, RJ : Vozes, 1999.

SALLES, Vicente. O Negro no Pará. Brasília: MEC; Belém: Secult, 1988. Disponível em https://fauufpa.files.wordpress.com/2013/03/o-negro-no-parc3a1-vicente-salles-pdf.pdf

Monografias, artigos, teses, dissertações e comunicações

DA SILVA, Vagner Gonçalves. Arte Religiosa Afro-Brasileira: as múltiplas estéticas da devoção brasileira. Debates do NER, Porto Alegre, Ano 09, N . 13, p. 97-113, JAN ./ JUN . 2008.

DEUS, Zélia Amador de. Regidos pelo Signos da Violência: as dores do racismo e da discriminação racial. In II Encontro da Sociedade Brasileira de Sociologia da Região Norte, disponível em < http://www.sbsnorte2010.ufpa.br> acesso em 19 de março de 2015.

HOFBAUER, Andreas. Uma História de Branqueamento ou o Negro em Questão. Tese de Doutorado, São Paulo, FFLCH/USP. 1999.

LEAL, Luiz Augusto Pinheiro. Nossos intelectuais e os chefes da mandinga: repressão, engajamento e liberdade de culto na Amazônia (1937-1951). Salvador: PMPGEEA/UFBA (Tese de doutorado), 2011.

BARROS, Raissa N. PINHEIRO, Tainara L. Exposição Nós de Aruanda - Artistas de terreiro. Construindo uma história de memória e resistência negra no Pará. In: IV Semana de Reflexões sobre a Negritude, Gênero e Raça do IFB - IV SERNEGRA e II Congresso de Pesquisadores(as) Negros(as) do Centro Oeste - II COPENE/CO, 2015, Brasília. Caderno de Resumos. Brasília: 2015. P. 30.

Artigos em jornais revistas e blogs

MUNANGA, Kabengele. A dimensão estética na arte negro-africana tradicional. São Paulo: MAC-USP, 7 de junho de 2006. Disponível em http://www.macvirtual.usp.br/mac/arquivo/noticia/Kabengele/Kabengele.asp consultado em 2 de maio de 2015

MUNANGA, K. Uma abordagem conceitual das noções de raça, racismo, identidade e etnia. In: Seminário Nacional Relaçoes Raciais e Educação - PENESB. Rio de Janeiro, 2003. Anais... Rio de Janeiro, 2003. Disponível em: $<$ http://www.acaoeducativa.org.br/downloads/09abordagem.pdf $>$. Acesso em: 23 de Dez. de 2015.

REIS. João José. Quilombos e revoltas escravas no Brasil. São Paulo: Revista USP, $\mathrm{n}^{\circ} 28$, dezembro de 1995 a fevereiro de 1996. P 14-39. Disponível em http://www.usp.br/revistausp/28/02-jreis.pdf consultado em 30 de dezembro de 2015

Leis

PORTUGAL, BRASIL Decreto s/n de 12 de agosto de 1816. Concede pensões a diversos artistas que vieram estabelecer-se no paiz. In Coleção de Leis do Império do Brasil - 1816, Página 77 Vol. 1 ver em http://bd.camara.gov.br/bd/handle/bdcamara/18330 
SEPPIR-PR. Programa de Combate ao Racismo Institucional. Brasília: SEPPIR, 2007.

Arquivo Público do Estado do Pará. Código de Posturas Municipais de 1880 - Título IV Capítulo XIX - -Das bulhas e vozeriasll. Aprovado pelos - Atos do Governo da Província do Grão-Pará - Tomo XLII - 1880 - Lei nº 1.028 de 05 de maio de 1880 - parte I.

\section{Outros documentos:}

F.C. PALMARES. Plano Nacional Setorial para as Culturas Afro-brasileiras. Brasília: F.C. Palmares. 2015 disponível em http://www.portalafricas.com.br/v1/wp-content/uploads/2015/11/Plano-Setorialpara-CulturaAfro-Brasilira-para-PUBLICA\%C3\%87\%C3\%83O-EM-NOV-2015-FINAL-1.pdf

Lista das CRQs Certificadas até 23-02-2015. Disponível em http://www.palmares.gov.br/wp-content/uploads/crqs/lista-das-crqs-certificadasate-23-022015.pdf Consultado em 29 de dezembro de 2015

GEAAM (NEAB)/ UFPA, Texto de apresentação da exposição Nós de Aruanda - artistas de terreiro, Galeria Theodoro Braga/ Fundação Cultural do Pará Tancredo Neves - GTBFCPTN/Governo do Pará. Belém, março de 2013.

\section{Entrevistas}

ETHNOS, Rodrigo. Exposição Nós de Aruanda - Artistas de terreiro. Entrevistadora: Tainara Pinheiro. Belém, 29 de maio de 2015b. Entrevista concedida ao Projeto Nós de Aruanda, artistas de terreiro/ GEAM - UFPA. In BARROS, Raissa N. PINHEIRO, Tainara L. Exposição Nós de Aruanda - Artistas de terreiro. Construindo uma história de memória e resistência negra no Pará. In: IV Semana de Reflexões sobre a Negritude, Gênero e Raça do IFB - IV SERNEGRA e II Congresso de Pesquisadores(as) Negros(as) do Centro Oeste - II COPENE/CO, 2015, 2015.

MACHADO, Joana Carmem Nascimento. Roda de conversa com a artista Joana Carmem Machado - contação de estórias afro-brasileiras. Entrevistadora: Luiza Soares Cabral Belém: Projeto Azuelar, Instituto Nangetu, 18 de abril de 2015. Entrevista concedida ao Programa "Nós de Aruanda na webTV Azuelar”. 22 min. Disponível em

https://www.youtube.com/watch?v=qmXr9GfWy4g Acesso em 24 de dezembro de 2015.

MAMETU NANGETU. Roda de conversa com Glauce Santos, Jean Ribeiro e Mametu Nangetu. Entrevistador: Arthur Leandro. Belém, 1 de maio de 2015a. Entrevista concedida para o Programa "Nós de Aruanda na webTV Azuelar. Disponível em https://www.youtube.com/watch?v=3wbQ8_iN5XA consultado em 28 de dezembro de 2015.

Fundamento - intervenção poética de Mametu Nangetu. Entrevistadores: Equipe do Projeto Azuelar, Belém, 3 de maio de 2015b Entrevista concedida para o Projeto Kiuá Nangetu. In LEANDRO, Arthur. LAGO, Isabela \& RODRIGUES, Oneide Monteiro. Kiuá Nangetu poéticas visuais de resistência negra. Belém: Instituto Nangetu. 2015.

SILVA, Samantha. Artistas de Aruanda. Entrevistadores: Arthur Leandro, Luah Sampaio, Luiza Cabral e Vitor Gonçalves. Belém, 10 de junho de 2014. Entrevista concedida para o Programa de Extensão "Mídias educativas de apoio à implantação da Lei 10.639/03" da PROEX/UFPA, para a construção de um documentário sobre a exposição Nós de Aruanda. 
SOUSA, Eduarda. Exposição Nós de Aruanda - Artistas de terreiro. Entrevistadora: Tainara Pinheiro. Belém, 29 de maio de 2015. Entrevista concedida ao Projeto Nós de Aruanda, artistas de terreiro/ GEAM - UFPA. In BARROS, Raissa N. PINHEIRO, Tainara L. Exposição Nós de Aruanda - Artistas de terreiro. Construindo uma história de memória e resistência negra no Pará. In: IV Semana de Reflexões sobre a Negritude, Gênero e Raça do IFB - IV SERNEGRA e II Congresso de Pesquisadores(as) Negros(as) do Centro Oeste - II COPENE/CO, 2015.

TATA KINAMBOJI. As mata tem morado! Obra invisível para população invisível/ espectador específico Totem monumento erguido na Mata da CEASA. Entrevistadores: Equipe do Projeto Azuelar, Belém 15 de maio de 2015. Entrevista concedida para o Projeto Kiuá Nangetu. In LEANDRO, Arthur. LAGO,Isabela \& RODRIGUES, Oneide Monteiro. Kiuá Nangetu poéticas visuais de resistência negra. Belém: Instituto Nangetu. 2015.

Sites

Floresta negra: A experiência e os impactos da escravidão africana na Região Amazônica Geledés

http://www.geledes.org.br/floresta-negra-experiencia-e-os-impactos-daescravidao-africana-naregiao-amazonica/\#ixzz3wCNYzJzl

Negritude.wikipedia https://pt.wikipedia.org/wiki/Negritude\#cite_ref-1

http://michaelis.uol.com.br/moderno/portugues/index.php?lingua=portuguesportugues\&palavra =denegrir 